Jurnal Tanah dan Sumberdaya Lahan Vol 8 No 1: 101-106, 2021

e-ISSN:2549-9793, doi: 10.21776/ub.jts1.2021.008.1.13

\title{
PENGARUH APLIKASI KOMPOS KOTORAN KAMBING DENGAN RESIDU UREA-HUMAT TERHADAP UNSUR P, K SERTA PERTUMBUHAN OKRA (Abelmoshus esculentus L.) PADA ENTISOL, WAJAK MALANG
Effect of Application of Goat Manure Compost with Urea-Humic Residues on P, K, and Growth of Okra (Abelmoshus esculentus L.) on an Entisol of Wajak Malang

\author{
Cahyo Bagus Susanto, Syahrul Kurniawan* \\ Jurusan Tanah, Fakultas Pertanian, Universitas Brawijaya, Jl. Veteran No 1, Malang 65145 \\ *Penulis korespondensi: syahrul.fp@ub.ac.id
}

\begin{abstract}
Entisol of Wajak Malang has low base saturation and organic matter and slightly acid. The result of the analysis also showed that soil has nutrient $\mathrm{P}$ with high criteria; however, $\mathrm{N}, \mathrm{K}, \mathrm{Ca}, \mathrm{Mg}, \mathrm{Na}$ contents are low to very low criteria. Application of humic acid at the first planting can leave residual nutrients and can still be used in the second planting. Besides urea-humic, goat manure can also be because it can improve soil properties, organic matter and nutrients contents. The purpose of this study was to explore the effect of the application of urea-humic residue with goat manure on the availability of phosphorus, potassium and the growth of okra on an Entisol of Wajak Malang. The combination of treatments consisted of: U1 (soil residue urea-humic 100\% + goat manure), UH1 (soil residue of urea-humic $75 \%+$ goat manure), UH2 (soil residue of urea-humic 100\% + goat manure), UH3 (soil residue of urea-humic 125\% + goat manure), UH4 (soil residue if urea-humic $150 \%+$ goat manure). The five treatments were arranged in a completely randomized design with three replicates. The results showed that urea-humic residue with application goat manure had no significant effect on available $\mathrm{P}$, exchangeable $\mathrm{K}$ in the soil, plants height and leaf number of okra on 4, 6 and 8 weeks after planting.
\end{abstract}

Keywords: available P, exchangeable K, Entisol, goat manure, urea-bumic

\section{Pendahuluan}

Tanaman Okra (Abelmoshus esculentus L.) merupakan jenis tanaman yang masuk dalan kategori sayur-sayuran. Tanaman ini kaya akan kandungan vitamin dan mineral. Menurut Kirana et al. (2017) setiap $100 \mathrm{~g}$ buah muda okra mengandung $90 \mathrm{~g}$ air, $2 \mathrm{~g}$ protein, $7 \mathrm{~g}$ karbohidrat, $1 \mathrm{~g}$ serat, $70-90 \mathrm{mg}$ kalsium dengan total energi sebesar $145 \mathrm{~kJ}$. Selain itu okra juga kaya akan kandungan vitamin A dan C, kalsium, thiamin dan ribhoflavin serta kaya akan zat besi yang dapat digunakan sebagai pengobatan penyakit radang dinding lambung (Uka et al., 2003). Namun di Indonesia sendiri budidaya okra masih kurang berkembang. Tanaman Okra dapat ditanam di berbagai jenis tanah, salah satunya adalah entisol. Entisol tersebar di seluruh Indonesia dengan total sebaran seluas 3.8 juta ha. Menurut Munir (1996), penyebaran paling luas terdapat di Kalimantan, Sumatera, Jawa, Sulawesi dan Bali. Di Indonesia Entisol banyak di gunakan sebagai areal persawahan yang baik. Entisol umumnya cukup mengandung unsur $\mathrm{P}$ dan $\mathrm{K}$ yang masih segar dan belum siap untuk diserap tanaman serta kekurangan unsur N (Darmawijaya, 1990) sehingga perlu dilakukan penelitian untuk meningkatkan kandungan unsur hara pada entisol sehingga dapat memenuhi kebutuhan 


\section{Jurnal Tanah dan Sumberdaya Lahan Vol 8 No 1: 101-106, 2021 e-ISSN:2549-9793, doi: 10.21776/ub.jts1.2021.008.1.13}

unsur hara bagi tanaman. Salah satu cara untuk mengatasi permasalahan pada entisol adalah dengan penambahan bahan organik. Pada penelitian ini bahan oraganik yang digunakan adalah asam humat. Asam humat dapat ketersediaan unsur makro dan unsur mikro bagi tanaman. Asam humat mempunyai kelebihan dalam meningkatan kandungan unsur hara N, $\mathrm{P}$, $\mathrm{K}, \mathrm{Ca}, \mathrm{Cu}, \mathrm{Fe}$ dan $\mathrm{Mn}$ dan perkecambahan tanaman okra lebih dari $80 \%$ (Paksoy et al., 2010). Hasil penelitian Suntari et al. (2015) menunjukkan bahwa perlakuan $100 \%$ ureahumat efektif untuk meningkatkan berat panen butir padi dan berat giling kering butir padi sebesar $22 \%$ dibandingkan perlakuan pupuk urea yang direkomendasikan (200 kg ha-1).

Bahan organik berikutnya yang dapat dimanfaatkan untuk meningkatkan kesuburan tanah dan ketersediaan unsur hara selain asam humat adalah pupuk kompos yang berasal dari kotoran kambing. Kadar hara pada kotoran kambing yaitu 46,51 \% C, 1,41\% N, C/N 32,98, $0,54 \%$ Pdan $0,75 \%$ K (Hartatik dan Widowati, 2006). Hasil penelitian (Hariadi et al., 2016) menunjukkan aplikasi kompos dari kotoran kambing $2 / 3$ ditambah $1 / 3$ tanah cukup optimal untuk meningkatkan pertumbuhan tanaman jagung. Berdasarkan uraian diatas, dilakukan penelitian mengenai pengaruh dari pengaplikasian residu urea humat dengan berbagai dosis ditambah dengan kompos kotoran kambing terhadap ketersediaan unsur $\mathrm{P}$ dan $\mathrm{K}$ serta kejenuhan basa pada entisol dan pertumbuhan tanaman okra.

\section{Bahan dan Metode}

Penelitian dilaksanakan pada bulan Januari 2017 hingga April 2017 di rumah kaca dan Laboratorium Kimia Tanah Fakultas Pertanian Universitas Brawijaya Malang. Analisis kimia tanah dan tanaman dilaksanakan di Laboratorium Kimia Jurusan Tanah Fakultas Pertanian Universitas Brawijaya Malang. Tanah yang akan digunakan dalam penelitian ini adalah Entisols yang diperoleh dari penelitian sebelumnya (Tampubolon dan Suntari, 2016). Tanah yang akan digunakan pada penelitian ini sebelumnya telah dilakukan analisis dasar untuk mengetahui sifat kimia tanah tersebut. Pada penelitian ini benih tanaman yang digunakan adalah benih tanaman Okra (Abelmoshus esculentus L.). Pupuk anorganik yang digunakan dalam penelitian ini adalah Urea sebagai sumber $\mathrm{N}$ dengan dosis $100 \mathrm{~kg} \mathrm{ha}^{-1}$, SP-36 sebagai sumber $\mathrm{P}$ dengan dosis $150 \mathrm{~kg} \mathrm{ha}^{-1}, \mathrm{KCl}$ sebagai sumber $\mathrm{K}$ dengan dosis $150 \mathrm{~kg} \mathrm{ha}^{-1}$. Pupuk organik yang digunakan dalam penelitian ini adalah pupuk kompos kotoran kambing yang diperoleh dari UPT Kompos Fakultas Pertanian Universitas Brawijaya. Bahan kimia yang digunakan untuk analisis tanah di Laboratorium Jurusan Tanah Fakultas Pertanian Universitas Brawijaya,yang meliputi analisis $\mathrm{pH}, \mathrm{P}$, dan $\mathrm{K}$ pada tanah.

Penelitian ini menggunakan metode penelitian Rancangan Acak Lengkap (RAL) dengan 5 perlakuan diulang sebanyak 3 kali. Perlakuan pada penelitian ini adalah sebagai berikut: U1= $2 / 3$ tanah residu Urea $100 \%+1 / 3$ Kompos Kotoran Kambing; UH1= 2/3 tanah residu Urea Humat $75 \%+1 / 3$ Kompos Kotoran Kambing; UH2 $=2 / 3$ tanah residu Urea Humat $100 \%+1 / 3$ Kompos Kotoran Kambing; UH3 = 2/3 tanah residu Urea Humat $125 \%+1 / 3$ Kompos Kotoran Kambing; UH4 $=2 / 3$ tanah residu Urea Humat 150\% + 1/3 Kompos Kotoran Kambing. Pengambilan data dilakukan pada awal tanam, 4MST, 6MST, dan 8 MST. Data yang telah didapatkan dilakukan analisis menggunakan analisis sidik ragam atau Analysis of Variance (ANOVA) berdasarkan metode Rancangan Acak Lengkap (RAL). diuji dengan uji $\mathrm{F}$ taraf $5 \%$. Apabila terdapat pengaruh perlakuan diuji DMRT (Duncan Multiple Range Test) dengan taraf 5\%.

\section{Hasil dan Pembahasan}

\section{Analisis tanah awal}

Sifat kimia tanah yang berasal dari residu ureahumat pada Entisol yang ditanami jagung menghasilkan nilai $\mathrm{pH}$ yang termasuk dalam kriteria agak masam yaitu antara 5,7 hingga 5,9. Nilai $\mathrm{pH}$ pada semua perlakuan berada pada kisaran yang sama. Dari hasil analisis tanah didapatkan nilai $\mathrm{P}$ tersedia berada pada kisaran 40,25 $\mathrm{mg} \mathrm{kg}^{-1}$ hingga 43,09 $\mathrm{mg} \mathrm{kg}^{-1}$ dengan kriteria tinggi dan nilai K-dd pada residu ureahumat termasuk dalam kriteria sangat tinggi yang berada pada kisaran 5,29 me K $100 \mathrm{~g}^{-1}$ hingga 5,64 me K $100 \mathrm{~g}^{-1}$. 


\section{Jurnal Tanah dan Sumberdaya Lahan Vol 8 No 1: 101-106, 2021 e-ISSN:2549-9793, doi: 10.21776/ub.jts1.2021.008.1.13}

Tabel 1. Hasil analisis residu urea-humat setelah pertanaman jagung.

\begin{tabular}{|c|c|c|c|}
\hline Kode & $\mathrm{pH}$ & $\begin{array}{l}\text { P tersedia } \\
\left(\mathrm{mg} \mathrm{kg}^{-1}\right)\end{array}$ & $\begin{array}{c}\text { K-dd } \\
\left(\mathrm{me} 100 \mathrm{~g}^{-1}\right)\end{array}$ \\
\hline U1 & 5,9 (agak masam) & 42,14 (tinggi) & 5,58 (sangat tinggi) \\
\hline UH1 & 5,7 (agak masam) & 40,25 (tinggi) & 5,57 (sangat tinggi) \\
\hline $\mathrm{UH} 2$ & 5,8 (agak masam) & 41,11 (tinggi) & 5,29 (sangat tinggi) \\
\hline UH3 & 5,7 (agak masam) & 42,14 (tinggi) & 5,56 (sangat tinggi) \\
\hline UH4 & 5,9 (agak masam) & 43,00 (tinggi) & 5,64 (sangat tinggi) \\
\hline
\end{tabular}

Keterangan: U1: Urea 100\%; UH1: Urea Humat 75\%; UH2: Urea Humat 100\%; UH3: Urea Humat 125\%; UH4: Urea Humat $150 \%$

\section{Fosfor (P) tanah}

Hasil analisis ragam menunjukkan bahwa residu urea-humat dengan aplikasi kompos kotoran kambing tidak berpengaruh nyata terhadap Ptersedia tanah pada pengamatan 4, 6 dan 8 MST. Ketersediaan $\mathrm{P}$ dalam tanah setelah pengaplikasian kompos kotoran kambing dan residu urea-humat pada seluruh pengamatan mengalami fluktuasi, tetapi tetap dalam kriteria yang sama dengan analisis tanah awal yaitu tinggi. Tidak terlihatnya pengaruh perlakuan urea-humat dengan aplikasi kompos kotoran kambing pada $\mathrm{P}$ tersedia tanah selama 8 MST diduga karena adanya pengaruh aplikasi pupuk dasar (SP-36). Unsur P dibutuhkan tanaman dalam jumlah yang sedikit yaitu $875-1850 \mathrm{mg}$ berdasarkan Wahyudi (2011) sehingga masih tercukupi oleh adanya penambahan pupuk Sp36. Akibatnya, perbedaan residu Urea-Humat dan aplikasi kompos kotoran kambing belum menunjukkan pengaruh yang nyata karena kondisi awal tanah memiliki konsetrasi $\mathrm{P}$ yang tinggi. Hasil penelitian menunjukkan adanya kecenderungan penurunan konsentrasi $\mathrm{P}$ tersedia tanah pada 4MST dan 6 MST, namun meningkat lagi pada 8 MST. Hal ini diduga karena $\mathrm{P}$ anorganik yang dilepaskan oleh mikroba diserap kembali oleh mikroba itu sendiri atau mikroba lain (Rosmarkam dan Yuwono, 2002). Selanjutnya, pada pengamatan 8 MST mengalami peningkatan nilai $\mathrm{P}$ tersedia dari analisis residu tanah disebabkan oleh mikroba yang mati akan melepaskan kembali $\mathrm{P}$ organik menjadi $\mathrm{P}$ anorganik (Rosmarkam dan Yuwono, 2002).

Tabel 2. Pengaruh residu urea-humat dengan aplikasi kompos kotoran kambing terhadap P-tersedia tanah.

\begin{tabular}{|c|c|c|c|c|c|c|}
\hline \multirow[t]{2}{*}{ Perlakuan } & \multicolumn{6}{|c|}{ P-tersedia $\left(\mathrm{mg} \mathrm{kg}^{-1}\right)$} \\
\hline & 4 MST* & $+(\%)$ & 6 MST* & $+(\%)$ & 8 MST* & $+(\%)$ \\
\hline U1 & 45,58 & 0 & 41,97 & 0 & 40,95 & 0 \\
\hline UH1 & 40,77 & $-4,28$ & 39,91 & $-2,1$ & 41,28 & 3,40 \\
\hline UH2 & 43,18 & $-0,42$ & 39,56 & $-2,3$ & 40,28 & $-0,12$ \\
\hline UH3 & 40,42 & $-4,08$ & 40,60 & $-0,42$ & 41,11 & 3,10 \\
\hline UH4 & 45,07 & $-0,08$ & 42,83 & 2,90 & 43,18 & 3,80 \\
\hline
\end{tabular}

Keterangan: (MST): Minggu Setelah Tanam; Perlakuan (U1): Tanah Residu Urea 100\% + Kompos Kotoran Kambing; (UH1): Tanah Residu Urea-Humat 75\% + Kompos Kotoran Kambing; (UH2): Tanah Residu UreaHumat 100\% + Kompos Kotoran Kambing; (UH3): Tanah Residu Urea-Humat 125\% + Kompos Kotoran Kambing; (UH4): Tanah Residu Urea-Humat 150\% + Kompos Kotoran Kambing. Kriteria sifat kimia tanah T: tinggi (Balai Penelitian Tanah, 2009).

\section{Kalium (K) tanah}

Hasil analisis ragam menunjukkan bahwa residu urea-humat dengan aplikasi kompos kotoran kambing tidak berpengaruh nyata terhadap $\mathrm{K}$ pada tanah pada pengamatan yaitu 4, 6 dan 8 MST. Apabila dibandingkan dengan kontrol 


\section{Jurnal Tanah dan Sumberdaya Lahan Vol 8 No 1: 101-106, 2021 e-ISSN:2549-9793, doi: 10.21776/ub.jts1.2021.008.1.13}

(residu urea), konsentrasi K-dd pada residu urea-humat dalam berbagai dosis menunjukkan kecenderungan yang lebih tinggi (meskipun tidak nyata pada taraf $5 \%$ ) berkisar antara $1,4-$ $8 \%$ pada 6 dan 8 MST. Tidak ditemukannya perbedaan yang nyata antar perlakuan terhadap konsentrasi K-dd tanah selama 8 MST diduga karena adanya pengaruh aplikasi pupuk dasar $(\mathrm{KCl})$ dan kompos kotoran kambing serta kondisi awal tanah yang digunakan dalam penelitian memiliki konsentrasi K-dd yang sangat tinggi. Menurut Safuan et al. (2016), kadar $\mathrm{K}$ total dalam tanah berkisar antara $0,01 \%$ hingga $4 \%$ tergantung pada jenis tanah, namun hanya $2 \%$ dari jumlah tersebut berada dalam bentuk larutan maupun $\mathrm{K}$ yang dapat dipertukarkan sehingga $98 \%$ sisanya berada dalam bentuk mineral atau $\mathrm{K}$ struktural yang tidak tersedia bagi tanaman. Tingginya kriteria K-dd dalam tanah diduga disebabkan oleh aplikasi kompos kotoran kambing yang digunakan sebagai campuran media tanam mengandung unsur hara $\mathrm{K}$ dengan kriteria sedang sehingga unsur hara $\mathrm{K}$ tersebut telah berubah menjadi dalam bentuk $\mathrm{K}+$ tersedia yang dapat dimanfaatkan oleh tanaman okra.

Tabel 3. Pengaruh residu urea-humat dengan aplikasi kompos kotoran kambing terhadap K-dd tanah.

\begin{tabular}{|c|c|c|c|c|c|c|}
\hline \multirow[t]{2}{*}{ Perlakuan } & \multicolumn{6}{|c|}{ K-dd (me $\left.100 \mathrm{~g}^{-1}\right)$} \\
\hline & 4 MST* & $+(\%)$ & 6 MST* & $+(\%)$ & 8 MST* & $+(\%)$ \\
\hline U1 & 5,77 & 0 & 5,39 & 0 & 5,42 & 0 \\
\hline UH1 & 5,48 & $-1,53$ & 5,42 & 1,96 & 5,65 & 7,53 \\
\hline UH2 & 5,61 & $-0,95$ & 5,41 & 6,51 & 5,56 & 4,88 \\
\hline UH3 & 5,34 & $-4,09$ & 5,48 & 4,74 & 5,52 & 1,42 \\
\hline UH4 & 5,88 & 4,25 & 5,64 & 8,00 & 5,71 & 2,17 \\
\hline
\end{tabular}

Keterangan: (MST): Minggu Setelah Tanam; Perlakuan (U1): Tanah Residu Urea 100\% + Kompos Kotoran Kambing; (UH1): Tanah Residu Urea-Humat 75\% + Kompos Kotoran Kambing; (UH2): Tanah Residu UreaHumat 100\% + Kompos Kotoran Kambing; (UH3): Tanah Residu Urea-Humat 125\% + Kompos Kotoran Kambing; (UH4): Tanah Residu Urea-Humat 150\% + Kompos Kotoran Kambing. Kriteria sifat kimia tanah T: tinggi (Balai Penelitian Tanah, 2009).

Unsur hara berada dalam keadaan tersedia jika $\mathrm{pH}$ tanah berada pada kisaran 5,5-6,5 (Suntari et al., 2015). Hasil penelitian Tampubolon dan Suntari (2016) menunjukkan bahwa pH Entisol setelah penambahan urea humat sebelum ditanami jagung adalah $6-6,9$. Hal ini tidak jauh berbeda dengan $\mathrm{pH}$ tanah pada musim kedua setelah penambahan kompos kotoran kambing yaitu 5,7-5,9. Menurut Tampubolon dan Suntari (2016), penambahan urea humat berpengaruh nyata terhadap pertambahan C-organik tanah, N-tersedia, dan KTK tanah serta pertumbuhan tanaman jagung. Pada penanaman musim kedua, penambahan kompos kotoran kambing terhadap residu urea humat pada Entisol tidak berpengaruh nyata terhadap penambahan unsur $\mathrm{P}$, dan $\mathrm{K}$ serta pertumbuhan tanaman okra.

\section{Tinggi tanaman}

Hasil analsis ragam menunjukkan bahwa residu urea-humat dengan aplikasi kompos kotoran kambing tidak berpengaruh secara nyata terhadap tinggi tanaman okra pada setiap pengamatan. Residu urea-humat dengan aplikasi kompos kotoran kambing meningkatkan tinggi tanaman okra. Hal ini kemungkinan karena pada setiap perlakuan diaplikasikan kompos kotoran kambing dengan jumlah yang sama yaitu $3 \mathrm{~kg}$ polibag- $^{-1}$. Menurut Ojeniyi et al. (2007), aplikasi kompos kotoron kambing sebanyak $12,5 \mathrm{t} \mathrm{ha}^{-1}$ tidak memberikan pengaruh nyata terhadap tinggi tanaman tomat dibanding perlakuan kontrol. Tinggi tanaman pada penelitian ini dipengaruhi oleh perlakuan. $\mathrm{Hal}$ ini menunjukkan bahwa ketersediaan unsur $\mathrm{P}$ dan $\mathrm{K}$ pada tanah dari residu urea-humat dengan aplikasi kompos kambing diserap oleh tanaman untuk mendukung pertumbuhan tanaman okra. Menurut Suntari et al., (2015), penambahan kompos kotoran kambing pada tanah akan meningkatkan ketersediaan unsur hara $\mathrm{N}, \mathrm{P}, \mathrm{K}$, Ca dan $\mathrm{Mg}$, selain yang didapat dari residu urea humat, yang akan diserap tanaman untuk proses pertumbuhan dan perkembangannya. 


\section{Jurnal Tanah dan Sumberdaya Lahan Vol 8 No 1: 101-106, 2021 e-ISSN:2549-9793, doi: 10.21776/ub.jts1.2021.008.1.13}

Tabel 4. Pengaruh residu urea-humat dengan aplikasi kompos kotoran kambing terhadap tinggi tanaman okra.

\begin{tabular}{ccccccc}
\hline Perlakuan & \multicolumn{7}{c}{ Tinggi Tanaman $(\mathbf{c m})$} \\
\cline { 2 - 7 } & $\mathbf{4}$ MST & $\mathbf{+ ( \% )}$ & $\mathbf{6 ~ M S T}$ & $\mathbf{+ ( \% )}$ & $\mathbf{8 ~ M S T}$ & $\mathbf{+ ( \% )}$ \\
\hline U1 & 30,33 & 0 & 40,66 & 0 & 62,50 & 0 \\
UH1 & 30,66 & 1,08 & 42,00 & 3,29 & 68,00 & 8,80 \\
UH2 & 30,33 & 0 & 43,33 & 6,56 & 69,00 & 10,40 \\
UH3 & 31,00 & 2,20 & 41,33 & 1,64 & 71,50 & 14,40 \\
UH4 & 31,00 & 2,20 & 43,33 & 6,56 & 63,66 & 1,85 \\
\hline
\end{tabular}

Keterangan: Perlakuan (U1): Tanah Residu Urea 100\% + Kompos Kotoran Kambing; (UH1): Tanah Residu Urea-Humat 75\% + Kompos Kotoran Kambing; (UH2): Tanah Residu Urea-Humat 100\% + Kompos Kotoran Kambing; (UH3): Tanah Residu Urea-Humat 125\% + Kompos Kotoran Kambing; (UH4): Tanah Residu Urea-Humat 150\% + Kompos Kotoran Kambing; (MST): Minggu Setelah Tanam.

\section{Jumlah daun}

Hasil analsis ragam menunjukkan bahwa residu urea-humat dengan aplikasi kompos kotoran kambing tidak berpengaruh secara nyata terhadap jumlah daun tanaman okra pada setiap pengamatan. Residu urea-humat dengan aplikasi kompos kotoran kambing tidak memberikan pengaruh secara nyata terhadap jumlah daun. Jumlah daun tanaman okra pada 4 sampai 8 MST tidak dipengaruhi oleh perlakuan. Hal ini menunjukan bahwa jumlah daun memiliki pola yang sama dengan tinggi tanaman okra. Hal ini kemungkinan karena pada setiap perlakuan diaplikasikan kompos kotoran kambing dengan jumlah yang sama sehingga pertumbuhan vegetatif tanaman okra memiliki jumlah daun yang sama, tidak berbeda antar perlakuan residu urea-humat dengan perlakuan residu urea saja. Hal ini sejalan dengan penelitian Akanni dan Ojeniyi (2008) bahwa dengan perlakuan kompos 5, 10 dan $15 \mathrm{t} \mathrm{ha}^{-1}$ tidak memberikan pengaruh secara nyata pada jumlah daun tanaman bayam dibanding perlakuan kontrol (tanpa pupuk). Hasil yang sama juga diperoleh pada penelitian Zeng et al. (2001) bahwa aplikasi kompos kotoron kambing sebanyak $12 \mathrm{~kg}$ per plot tidak memberikan pengaruh secara nyata terhadap jumlah daun tanaman okra.

Tabel 5. Pengaruh residu urea-humat dengan aplikasi kompos kotoran kambing terhadap jumlah daun okra.

\begin{tabular}{ccccccc}
\hline Perlakauan & \multicolumn{7}{c}{ Jumlah Daun } \\
\cline { 2 - 7 } & 4 MST & $+\mathbf{( \% )}$ & $\mathbf{6}$ MST & $+\mathbf{+} \% \mathbf{)}$ & $\mathbf{8}$ MST & $+(\mathbf{\%})$ \\
\hline U1 & 5 & 0 & 7 & 0 & 11 & 0 \\
UH1 & 7 & 40,0 & 8 & 14,28 & 9 & $-18,18$ \\
UH2 & 6 & 20,0 & 8 & 14,28 & 9 & $-18,18$ \\
UH3 & 6 & 20,0 & 8 & 14,28 & 10 & $-9,09$ \\
UH4 & 5 & 0 & 9 & 28,57 & 11 & 0 \\
\hline
\end{tabular}

Keterangan: Perlakuan (U1): Tanah Residu Urea 100\% + Kompos Kotoran Kambing; (UH1): Tanah Residu Urea-Humat 75\% + Kompos Kotoran Kambing; (UH2): Tanah Residu Urea-Humat 100\% + Kompos Kotoran Kambing; (UH3): Tanah Residu Urea-Humat 125\% + Kompos Kotoran Kambing; (UH4): Tanah Residu Urea-Humat 150\% + Kompos Kotoran Kambing; (MST): MInggu Setelah Tanam.

\section{Kesimpulan}

Berdasarkan penelitian yang telah dilakukan, dapat disimpulkan bahwa aplikasi kompos kotoran kambing dengan residu urea-humat pada Entisol tidak berpengaruh nyata terhadap ketersediaan fosfat dan kalium pada entisol serta tinggi dan jumlah daun tanaman okra. 


\section{Jurnal Tanah dan Sumberdaya Lahan Vol 8 No 1: 101-106, 2021 e-ISSN:2549-9793, doi: 10.21776/ub.jts1.2021.008.1.13}

\section{Daftar Pustaka}

Akanni, D.I. and Ojeniyi, S.O. 2008. Residual effect of goat and poultry manures on soil properties nutrient content and yield of amanranthus in southwest Nigeria. Research Journal of Agronomy 2(2): 44-47.

Darmawijaya, I. 1990. Klasifikasi Tanah, Dasar-dasar Teori Bagi Penelitian Tanahdan Pelaksanaan Penelitian. UGM Press, Yogyakarta.

Hariadi, Y C., Nurhayati, A.Y. and Hariyani, P. 2016. Biophysical monitoring on the effect on composition of goat and cow manure on the growth respone of maize to support sustainability. International Journal of Agriculture 9: 118-127.

Hartatik, W. dan Widowati, L.R. 2006. Pupuk Kandang dalam Pupuk Organik dan Pupuk Hayati. Balai Besar Penelitian dan Pengembangan Sumberdaya Lahan Pertanian. Bogor. 59-79

Kirana, R., Gaswanto, R. dan Hidayat, I.M. 2017. Budidaya dan Produksi Benih Okra [Online].http://hortikultura.litbang.pertanian.go .id/teknologi-detail-21.html. (Verified 1 April 2017).

Munir, M. 1996. Tanah - Tanah Utama Indonesia Karakteristik: Klasifikasi dan Pemanfaatannya. Pustaka Jaya, Jakarta.

Ojeniyi, S.O. and Adegboyega, A.A. 2003. Effect of combined use of urea and goat manure on celosia. Nigerian Journal of Agriculture 54: 87-90.

Paksoy, M., Turkmen, O. and A. Dursun, A. 2010. Effect of pottasium and humic acid on emergence, growth and nutrient contents of okra (Abelmoschus esculentus L.) seedling under saline soil conditions. African Journal of Biothecnology $9(33): 5343-5346$.
Rosmarkan, A. dan Yuwono, N.W. 2002. Ilmu Kesuburan Tanah. Kanisius, Yogyakarta. p.156180.

Safuan, L.O., Poerwanto, R., Susila, A.D. dan Sobir. 2016. Rekomendasi pemupukan kalium untuk tanaman nenas berdasarkan status hara tanah. Jurnal Agronomi Indonesia 39(1):56-61, doi: 10.24831/jai.v39i1.13194

Suntari, R., Retnowati, R., Soemarno and Munir, M. 2015. Determination of urea- humic acid dosage of vertisols on the growth and production of rice. Agrivita 35 (2) : 185-192.

Tampubolon, Y.Y. dan Suntari, R. 2016. Pengaruh dosis urea-humat terhadap ketersediaan n pada Entisol dan serapan $\mathrm{N}$ oleh tanaman jagung. Jurnal Tanah dan Sumberdaya Lahan 4(2): 559565.

Uka, U.N., Chukwuka, K.S. and Iwuagwu, M 2003. relative effect of organic and inorganic fertilizer on the growth of okra (Abelmoschus esculentus (L.) Moench). Nigerian Journal of Agriculture 58 (3): 159-166.

Wahyudi. 2011. Pemanfaatan limbah cair pabrik kelapa sawit untuk memenuhi kebutuhan unsur hara dalam budidaya tanaman jagung (Zea mays L.). Jurnal Ilmu Lingkungan. 5 (2) :57-63

Zeng, Q., Brown, P.H. and Holtz, B.A. 2001. Potassium fertilization affects soil $\mathrm{K}$, leaf $\mathrm{K}$ concentration, and nut yield and quality of mature pistachio trees. Horticulture Science. $36(1): 85-89$. 